\title{
Comparison between Linear Regression, Support Vector Machines, and Neural Networks in Forecasting the Number of Foreign Tourist Visits to Indonesia
}

\author{
Fahirah*, Sutresna Wati $^{* *}$ \\ * Department of Management Information System, Gunadarma University \\ ** Department of Computer Engineering, Gunadarma University \\ DOI: 10.29322/IJSRP.11.05.2021.p11330 \\ http://dx.doi.org/10.29322/IJSRP.11.05.2021.p11330
}

\begin{abstract}
The tourism sector is one of the largest foreign exchange contributors to the country's economic growth. One of the determining factors for tourism development is the number of foreign tourist arrivals. It is necessary to carry out development, planning strategies that appropriate, effective, and efficient to increase foreign tourist arrivals. Business Intelligence is one of the digital trends and the main digital marketing strategy for Digital Tourism by implementing data mining for data analysis, including forecasting. There are various kinds of forecasting methods, but the problem is in choosing the best method for the problem and the desired output. This study aims to compare the accuracy between Linear Regression, Support Vector Machine (SVM), and Neural Network methods to forecast the number of foreign tourist arrivals to Indonesia using RapidMiner Studio and parameter of Root Mean Square Error (RMSE) to compare the accuracy of each method. The results of this study indicate the RMSE value of the SVM has the smallest RMSE value compared to the other two methods. SVM is used to make a forecast for the next period which can be used as a basis for the government and the tourism industry in making decisions.
\end{abstract}

Index Terms- Forecasting, Foreign Tourist Visits, Linear Regression, Neural Network, Support Vector Machine

\section{INTRODUCTION}

$\mathrm{T}$ he tourism sector has an important role in the Indonesian economy because it is one of the largest foreign exchange contributors to the country's economic growth [1]. All expenditures from tourists, investment, and government have an impact on increasing output, added value, income, and labor creation in Indonesia [2]. One of the determining factors for tourism development is the number of tourist visits, especially foreign tourists [3]. The number of foreign tourist visits to Indonesia increased by 1.88 percent in 2019, but in April 2020 it experienced a drastic decline due to a decrease in all main entrances for Ngurah Rai, Soekarno Hatta, and Batam [4]. According to Badan Pusat Statistik in [5], the number of foreign tourists visiting Indonesia in August 2020 decreased by 89.22 percent, which only reached 164.97 thousand visits when compared to August 2019 which amounted to 1.53 million visits.
To increase foreign tourist visits, it is necessary to carry out sustainable development in the tourism sector with proper planning, promotion strategies, and the need for synergy from central and local government, and society [6]. The development of technology has accelerated the dynamics of world globalization, including the development of tourism [7]. According to the Minister of Tourism, tourism development in Indonesia will rely on technology to accelerate growth and face the millennial era [8]. The presence of technology plays a very important role for tourists in tourism activities, from planning trips to after the trip. As for the country and the tourism industry, it plays a role in managing the tourism strategy itself [9]. The development carried out must be in line with the growth of foreign tourist visits so it is right on target, effective, and efficient [10]. To determine the growth of foreign tourist visits in the following years, it is necessary to forecast foreign tourist visits to Indonesia.

Forecasting foreign tourist visits is very important for government and industry as the basis for effective policy planning related to decisions making for the public and private sectors such as infrastructure, transportation, accommodation, and other services [3]. Forecasting is data mining analysis to predict future values using previous values [11]. Forecasting can be applied when historical data are available, can be quantified in numerical form, and can be assumed some aspects of past patterns will continue in the future [12]. Based on digital trends, Business Intelligence (BI) is one of the main digital marketing strategies for Digital Tourism by applying data mining for data analysis that can improve measurement strategies to obtain greater profitability within BI and companies [13]. BI technology provides a historical, current, and predictive view of business operations [14]. Data mining is the core of $\mathrm{BI}$ and forecasting is the core of predictive analytics in BI, which is widely applied in analyzing markets, inventory, and sales. There are various kinds of forecasting methods that can be implemented but the problem is in choosing the best forecasting method for the problem and the desired output which is greater accuracy in predicting future values from a particular dataset. A comparative study of forecasting methods is necessary before applying them to the needs of any organization [15]. This study aims to compare forecasting methods in data mining to forecast the number of foreign tourist visits to Indonesia. The methods being compared are Linear Regression, Support Vector Machine (SVM), and Neural Network using RapidMiner Studio as a tool and the value of Root Mean Squared Error (RMSE) as a 
measurement. The results of this study can be implemented into Business Intelligence (BI) which can be used by the government and industry as a basis for effective policy planning related to the tourism sector.

\section{STATE OF THE ART}

Linear Regression is a method of modelling the relationship between the dependent and independent variables that becomes the favorite statistical technique for prediction problems because easy to understand and implement [16][17]. It involves searching for the best line to match two attributes so one attribute can be used to predict the other [14]. SVM is a method for classifying data that can be separated linear and nonlinear [14][17]. It divided into two: Support Vector Classification (SVC) and Support Vector Regression (SVR) that can be used for numerical classification and prediction. It is highly accurate due to its ability to model complex non-linear decision boundaries and less prone to overfitting than other methods [17]. While Neural Network is a field of study that acquires knowledge by mapping and studying data using a method similar to how the human brain works [15]. Neural Network has three layers: input layer, hidden layer, and output layer that consists of a set of neurons connected by links [18]. According to Han in [14] and Brown in [16], this method is able to perform classification, prediction, and analysis because it has a high tolerance for noisy data, has the ability to classify untrained patterns, and can be used when there is little knowledge of the relationship between attributes and classes. Root Mean Square Error (RMSE) is a squared scoring rule that measures the average error value between the target and output values [19]. It is a method that is often used to evaluate forecasting results or calculate forecast errors [20]. The smaller the RMSE value, the better the accuracy of prediction [21].

Related research has been conducted by Thirunavukkarasu in [15] compares SVM and Neural Network shows SVM performance is found better than Neural Network when predicting. While according to Yoon in [19], the RMSE value of Neural Network is lower than the SVM, but the overall model performance criteria of SVM are similar or even better than Neural Networks. Other studies conducted by Setiyorini in [22] compare Linear Regression with Neural Networks and show the RMSE value of the Neural network is smaller than Linear Regression. Comparison of data mining algorithms carried out by Maulana and Kumalasari in [21] for the GGRM stock price prediction, including Neural Network, Linear Regression, SVM, and show the Neural Network has the smallest RMSE value compared to other algorithm models.

\section{RESEARCH METHOD}

This research consists of four main stages and can be seen in Figure 1.

\section{A. Data Preparation}

The data preparation stage is useful for forming a dataset that is ready to be used for the forecasting process. Data preparation consist of Data Collection, Data Cleaning and Data Integration, and Data Transformation. The data used are data on the number of foreign tourists visiting Indonesia per month (January 1999 to October 2020) and data on the number of tourist visits by nationality (January 2007 to October 2020) which were collected from several documents downloaded through the official website of the Badan Pusat Statistik (BPS) at https://www.bps.go.id accessed on 12 October 2020. The selected countries are 3 countries: Malaysia, Singapore, and the Philippines which are ASEAN countries.

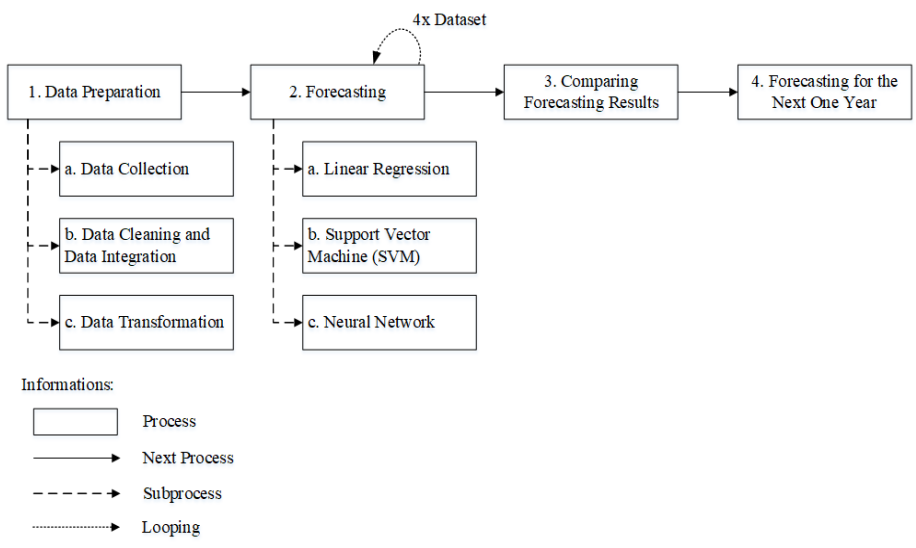

Figure 1 : Research Stages Scheme

Next, the data are transferred and combined into one excel file. Then, delete unnecessary columns, rows, and remove spaces in the column of the number of foreign visits so the data type is numeric. The data in the excel file transform into certain fields consists of 2 columns (attributes), the "Period" and "Number of Visits" columns. This stage is also carried out for data on foreign tourist visits to Indonesia based on nationality, Malaysia, Singapore, and the Philippines. The number of data on the number of foreign tourist visits to Indonesia is 260 data, while the number of data on foreign tourist visits to Indonesia based on nationality is 166 data for each country.

\section{B. Forecasting}

A forecasting model is made using the RapidMiner Studio version 9.8. The modeling carried out from each method is similar, where the initial forecasting process is done by reading the dataset with the Read Excel operator. Attribute "Period" is used as an ID and "Number of Visits" as a regular attribute. Windowing operator is used to transform data into several attributes according to the specified window size. It is a technique for determining input data and output data in predicting time series data with univariate type. The attribute index parameter (related to the time series) is selected "Period", the window size is set to 12 indicating the number of attributes, the step size is set to 1 , and select "Total Visits" on the attribute horizon which shows the predicted label or attribute. The new dataset is formed which consists of 1 ID attribute, 12 ordinary attributes as input data, and 1 label as output data. A split data operator is used to dividing the dataset into two parts (training and testing data) using a split data ratio of 7: 3 and 9: 1 with automatic sampling type. Testing data is connected to the operator of each method and testing data to the Apply Model operator. Then, the Performance Operator is used to calculate the RMSE of each method. The output of this stage is the forecasting result from data testing and the RMSE value as the accuracy value. The forecasting stage are repeated as many datasets and methods 
are used. Figure 2 is an overview of forecasting flows using (a) Linear Regression, (b) SVM, and (c) Neural Network.

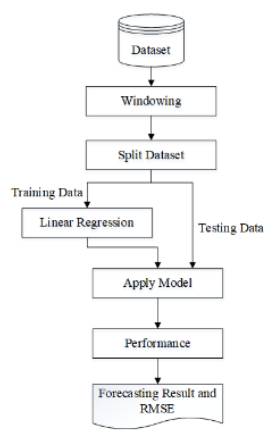

(a) Linear Regression

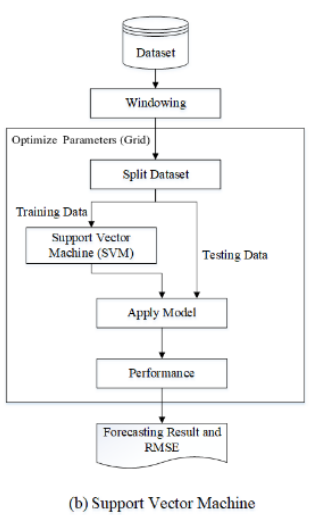

Figure 2 : Forecasting Schemes

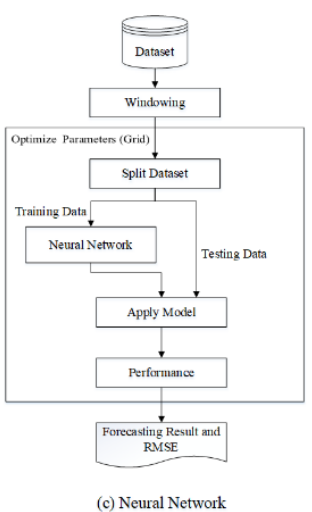

(c) Neural Network

\section{- Linear Regression}

Parameters set are using the defaults from RapidMiner and feature selection is changed to "none". The resulting model forms an equation like in Eq. (1). $\mathrm{Y}$ or $\mathrm{f}(\mathrm{x})$ is the result of forecasting and $X_{(1,2,3, \ldots)}$ is the value of each attribute. The coefficient $t_{(1,2,3, \ldots)}$ is the coefficient generated from each attribute and a is the y-intercept generated from the training data process. The resulting model is used to forecast the number of foreign tourist visits per month by using data testing which is entered into the $\mathrm{X}_{0}$ to $\mathrm{X}_{11}$.

$$
Y=f(x)=\text { Coefficient }_{0} * X_{0}+\text { Coefficient }_{1} * X_{1}+\cdots+
$$$$
\text { Coefficient }_{n} * X_{n}+a
$$

\section{- Support Vector Machine (SVM)}

The Optimize Parameters (Grid) operator is used to determine the optimal value for the parameters selected in the model by running a subprocess for all selected value combinations. The selected SVM parameters are the $\mathrm{C}$ and the $\varepsilon$ value. The $\mathrm{C}$ is the tolerance for misclassification errors used for the training process which will provide an alpha limit value. A high $\mathrm{C}$ value indicates the soft margin is used. The risk of using a high $\mathrm{C}$ value can lead to overfitting the model, while if the $\mathrm{C}$ value is too low it makes the model too generalize in the classification. The $\varepsilon$ is used to measure empirical risk, the difference between the output/target and the estimation results, so it must be adjusted. The value of $\mathrm{C}$ is set in the range of -1.0 to 10 and the value of $\varepsilon$ is set in the range of 0.1 to 10 . For other SVM parameter values is used the default from RapidMiner. The resulting model forms an equation like in Eq. (2).

$$
Y=f(x)=w_{0} * \phi\left(x_{0}\right)+w_{1} * \phi\left(x_{1}\right)+\cdots+w_{n} * \phi\left(x_{n}\right)+b
$$

$Y$ or $f(x)$ is the result of forecasting, $\phi(x i)$ is the function that maps the value of $\mathrm{x}$ in a dimension, and $\mathrm{x}$ is the value of each attribute. The $\mathrm{w}$ is the weighting vector and $\mathrm{b}$ is the bias value generated from the training data process. The resulting model is used to forecast the number of foreign tourist visits per month by using data testing which is entered into the function $\phi(x i)$.

\section{- Neural Network}

The Optimize Parameters (Grid) operator on Rapid Miner is also used in Neural Network. The selected Neural Network parameter is the Learning Rate which is useful for speeding up training. It needs to be adjusted because a Learning Rate that is too large can reduce accuracy and also slow down the training, otherwise, if the learning rate is too small the use of resources will be smaller and reduce a significant increase in accuracy. Learning Rate values are set in the range of 0.0 to 0.1 , while for other Neural Network parameter values, this study uses the default of RapidMiner. The resulting model forms 1 input layer (consists of 12 nodes which represent the number of data attributes used, and 1 bias node), 1 hidden layer, and 1 output layer (consists of 1 node which is the result of forecasting). The nodes in the hidden layer and the weight value of each node are formed from the training data process. The resulting model is used to forecast the number of foreign tourist visits per month using testing data.

\section{RESULT AND ANALYSIS}

\section{A. Forecasting Using Linear Regression}

Figure 3 shows the workflow of forecasting foreign tourist visits to Indonesia using Linear Regression that designed in RapidMiner that executed with split data ratio of 7:3 and 9:1. The graph of forecasting results for foreign tourist visits to Indonesia using Linear Regression with the ratio of 7:3 can be seen in Figure 4 and for the ratio of 9:1 can be seen in Figure 5 that shows the green line as the results of forecasting, while the blue line as the actual data.

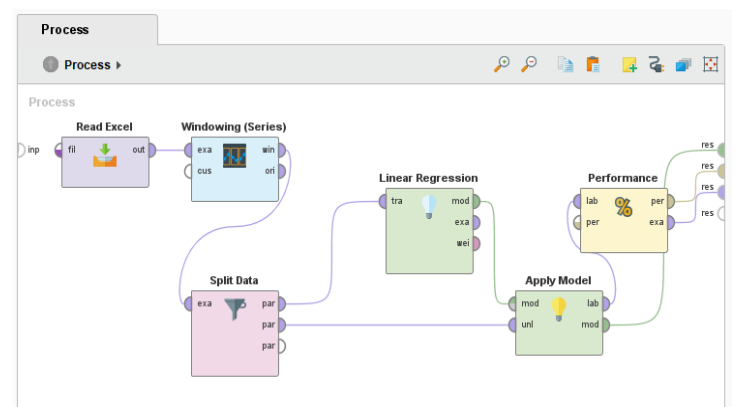

Figure 3 : Forecasting Workflow using Linear Regression

\section{B. Forecasting Using Support Vector Machine (SVM)}

Figure 6 shows the workflow of forecasting foreign tourist arrivals to Indonesia using SVM that designed in RapidMiner that executed with ratios of 7:3 and 9:1 on the Split Data operator. The graph of forecasting results for foreign tourist visits to Indonesia using SVM with the ratio of 7:3 can be seen in Figure 7 and for the ratio of 9:1 can be seen in Figure 8 that shows the green line as the results of forecasting, while the blue line as the actual data. 


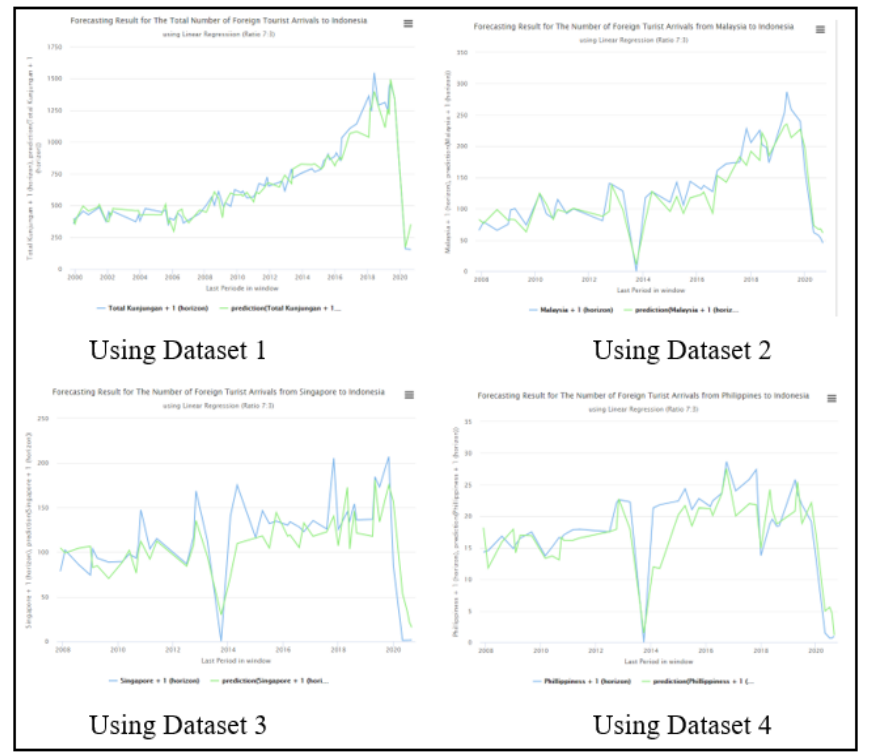

Figure 4 : Forecasting Result using Linear Regression (Split Data Ratio of 7:3)

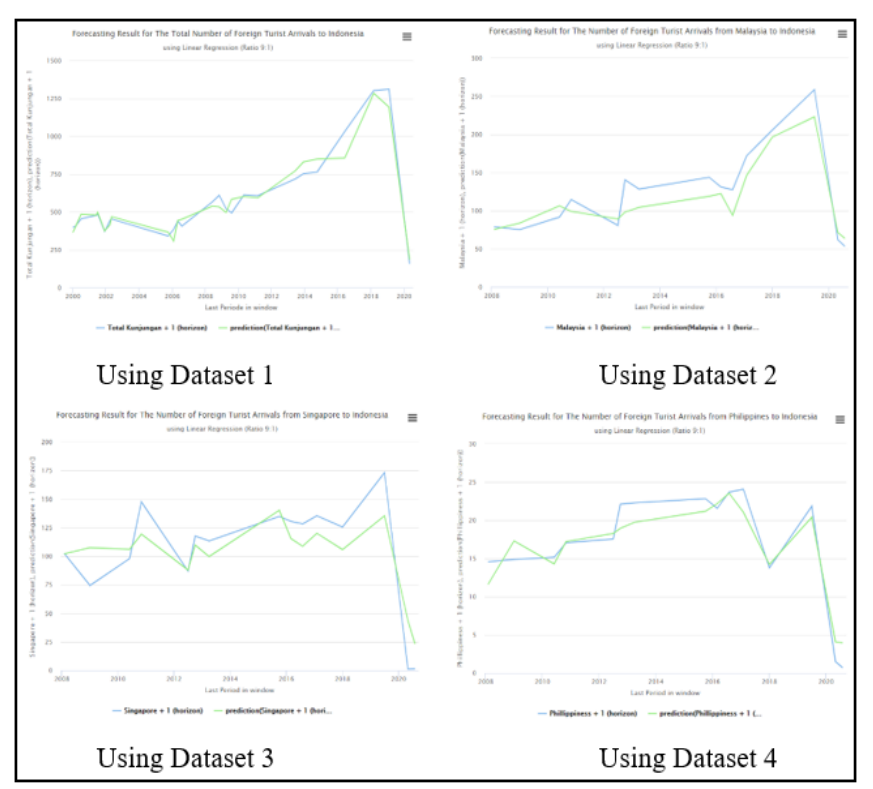

Figure 5 : Forecasting Result using Linear Regression (Split Data Ratio of 9:1)
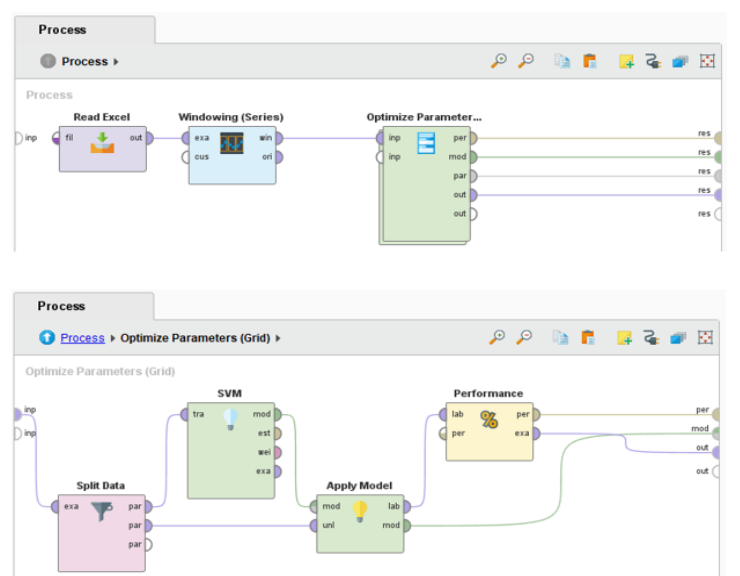

Figure 6 : Forecasting Workflow using SVM

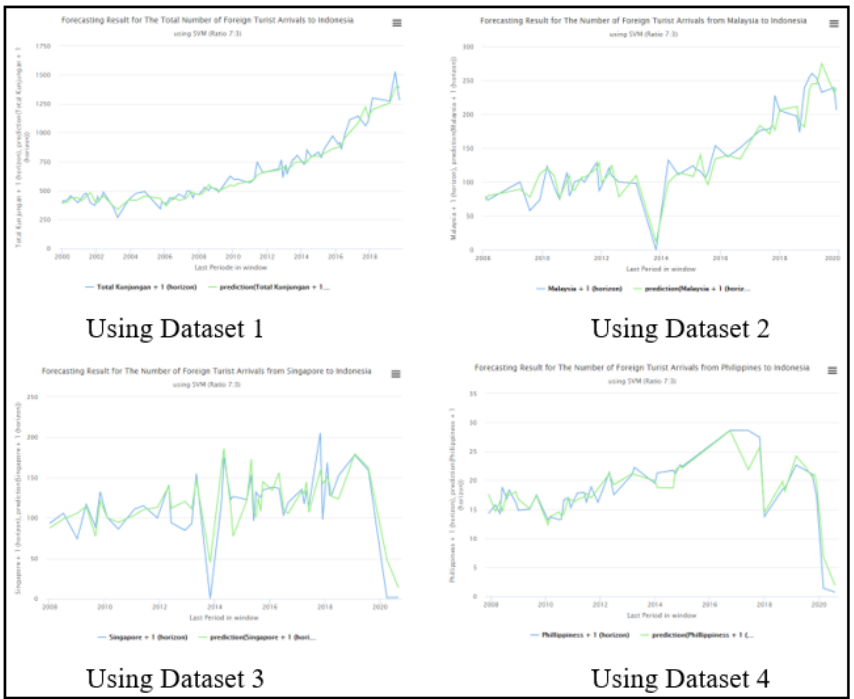

Figure 7 : Forecasting Result using SVM (Split Data Ratio of $7: 3)$

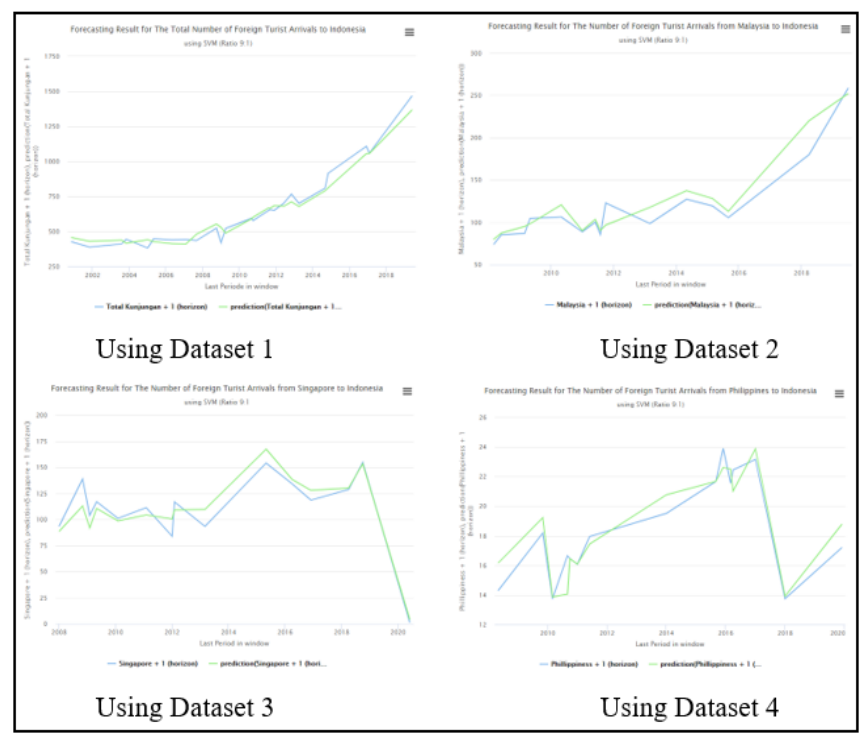

Figure 8 : Forecasting Result using SVM (Split Data Ratio of $9: 1)$

\section{Forecasting Using Neural Network}

The overall workflow of forecasting foreign tourist arrivals to Indonesia using Neural Network that designed in RapidMiner is the same as in Figure 6, the difference is only in the method operators. It also executed with ratios of 7:3 and 9:1 on the Split Data operator. The graph of forecasting results for foreign tourist visits to Indonesia using Neural Network with the ratio of 7:3 can be seen in Figure 9 and for the ratio of 9:1 can be seen in Figure 10 that shows the green line as the results of forecasting, while the blue line as the actual data. 


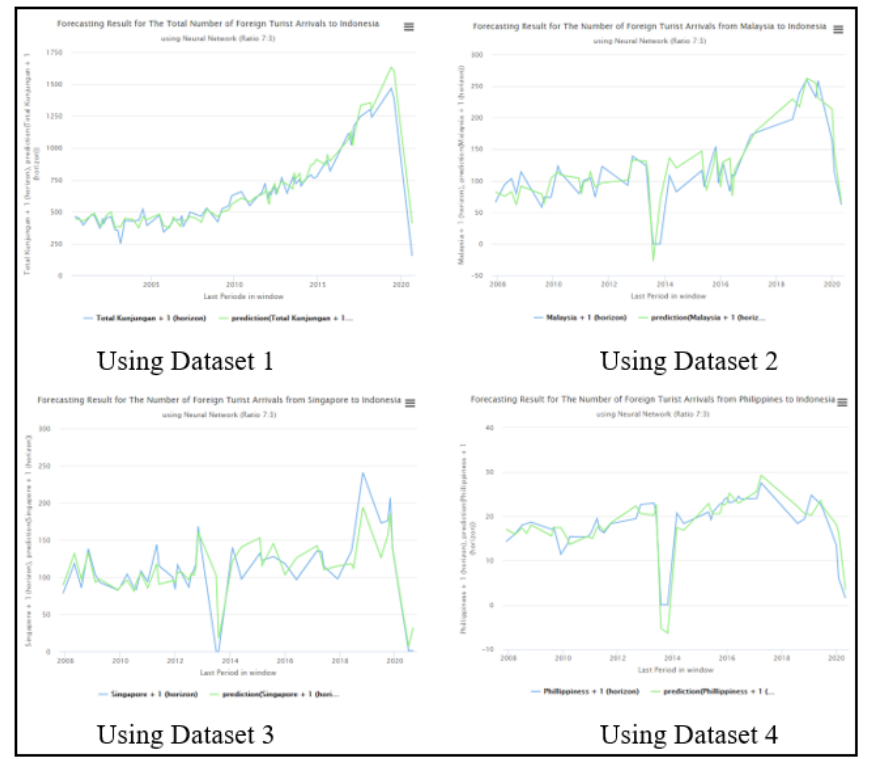

Figure 9 : Forecasting Result using Neural Network (Split Data Ratio of 7:3)

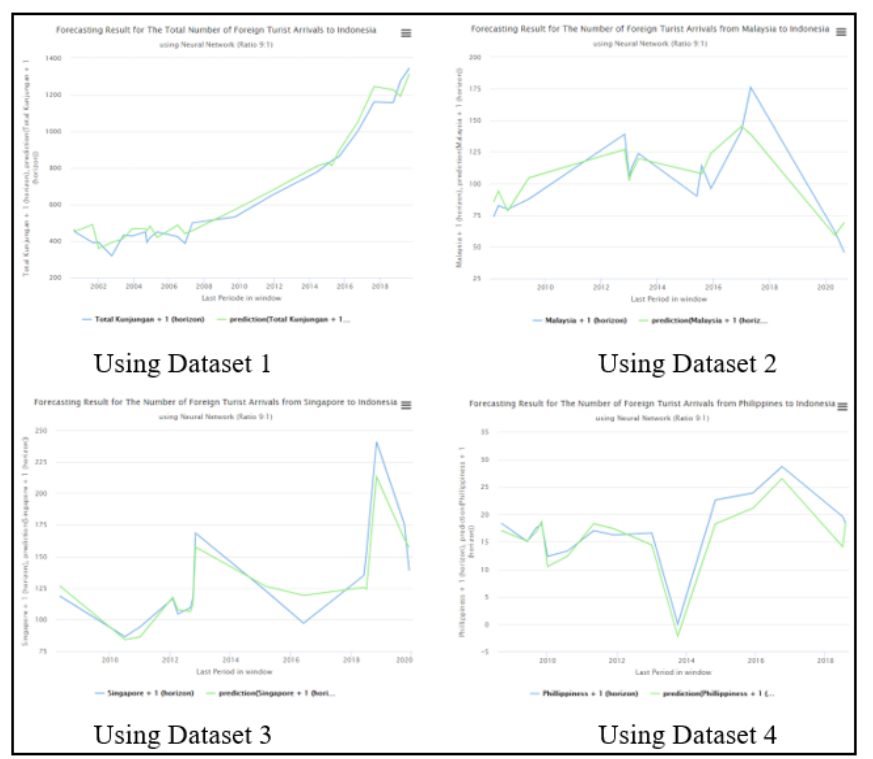

Figure 10 : Forecasting Result using Neural Network (Split Data Ratio of 9:1)

\section{Comparing Forecasting Result}

Comparisons between models were carried out using the Root Mean Squared Error (RMSE) value of each method. The forecasting method that produces the smallest RMSE value is chosen as the forecasting method that has the highest accuracy among the three methods being compared to forecasting the number of foreign tourist visits to Indonesia per month.

The comparison of the RMSE value for each method and the split data ratio in all datasets can be seen in Figure 11. It can be seen that the RMSE value in each method using split data ratio of 9:1 is smaller than using split data ratio of 7:3 in all dataset. This shows that the amount of training data will positively affect the accuracy of the forecast. The more training data used, the more accurate the forecasting results.
The RMSE of SVM shows more training data can produce better forecasts, but based on [23], SVM does not require large amounts of data because it has the ability to overcome overfitting. SVM has several parameters that must be adjusted, including the value of $\mathrm{C}$ and Epsilon. The comparison of the optimal $\mathrm{C}$ and Epsilon values from each dataset can be seen in Figure 12. These results indicate that the determination of the SVM parameter also affects the accuracy of the forecasting results and as Harafani and Wahono said in [23], it is difficult to determine the optimal SVM parameter value because each dataset will have different optimal parameters. Neural Networks also have parameters that need to be set, including the Learning Rate value that must be set to train Neural Networks and also plays a role in updating the weight parameter values [24]. The comparison of the optimal learning rate values from each dataset can be seen in Figure 13.

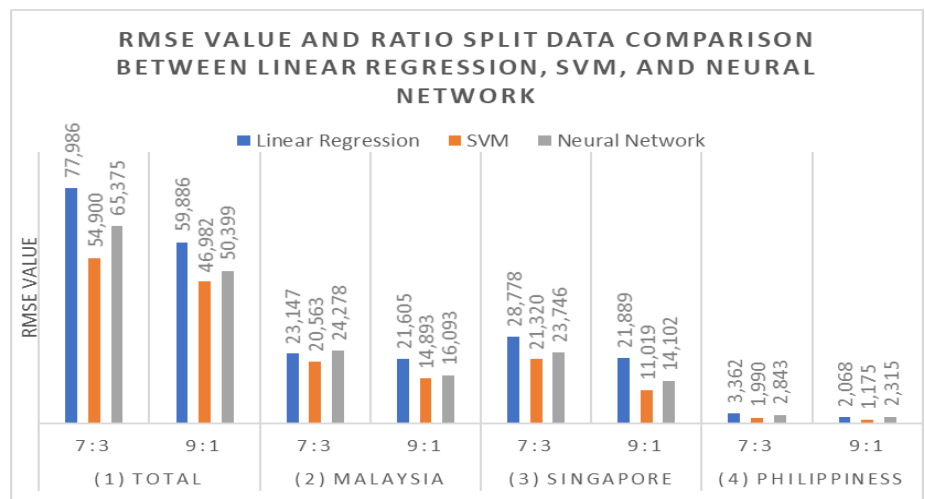

Figure 11 : Comparison of the RMSE Value of the Three Forecasting Methods

Based on Figure 11, the overall SVM has the smallest RMSE value. It shows that SVM has a higher accuracy value than the two methods being compared. The order of the best methods based on the resulting RMSE value is SVM, Neural Network, and Linear Regression. The results of this study are in line with the results in [22] which shows Neural Networks is better than Linear Regression and in line with the results in [15] which show that SVM is better than Neural Network when predicting. The results of this study also prove the statement in [14][15] which states that SVM can efficiently represent complex non-linear relationships and is much less prone to overfitting than other methods so that SVM has the best accuracy value. While Neural Networks can process and represent complex input and output relationships or linear and non-linear relationships from data models and have a high tolerance for data noise as stated in [16], however the accuracy value of Neural Networks in this study is lower than SVM. This can happen because the parameter range specified is not suitable so that the accuracy decreases or because the Neural Network method has not been optimized. Meanwhile, Linear Regression is also proven to be unable to handle complex problems and non-linear data so that it has the lowest accuracy of SVM and Neural Networks 


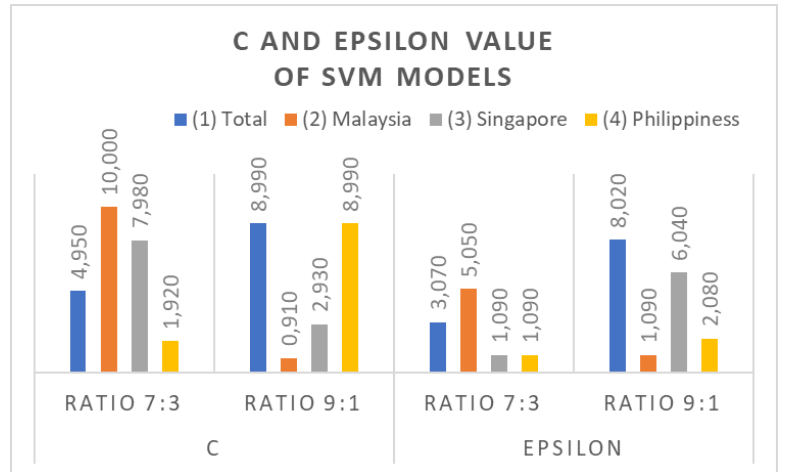

Figure 12 : C Value of Support Vector Machine (SVM)

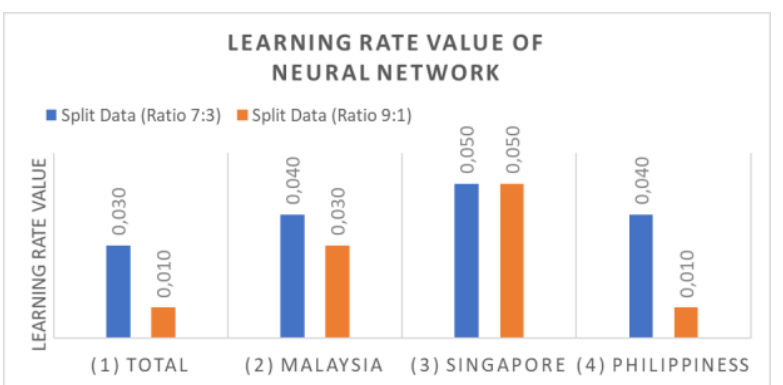

Figure 13 : Learning Rate Value of Neural Network Models

\section{E. Forecasting Using the Chosen Method}

In this stage, SVM is used to forecasts the number of foreign tourist visits to Indonesia using the same four datasets for the next year starting from November 2020 to October 2021. Figure 14 shows the forecasting result for the number of foreign tourist visits to Indonesia in the next year. This result can be used as a basis for making policies or decisions for both the government and the tourism industry. For the government, it can be used to anticipate the growth in the number of foreign tourist arrivals to Indonesia by providing the infrastructure and services needed. For the tourism industry, it can be used to see the development of foreign tourist visits based on nationality for seeing existing opportunities, maximizing them, and minimizing possible risks. By knowing the results of forecasting visits based on nationality, the tourism industry can form the basis for policy-making related to the provision of services, attractions, goods, and promotions that can attract foreign tourist arrivals and also determine target markets and performance targets for the coming period.

For example, Figure 14 shows that on February 2021 experienced the highest increase, therefore the government and the tourism industry can prepare or develop transportation facilities, accommodation, tourist attractions, etc. that are needed by foreign tourists. In addition, they can carry out more attractive promotions for March 2021 and beyond so that the number of foreign tourist arrivals does not decrease. From the results of forecasting based on nationality, the government and the tourism industry can carry out promotions with a focus on the countries that are predicted to decline, such as Singapore from July 2021 to October 2021. Promotion can be done through social media because according to Kemp in [25], in $202049 \%$ of the total population (3.8 billion people) are active users of social media with a growth of $9.2 \%$ from the previous year. The three most popular social media in the world are Facebook, YouTube and WhatsApp.

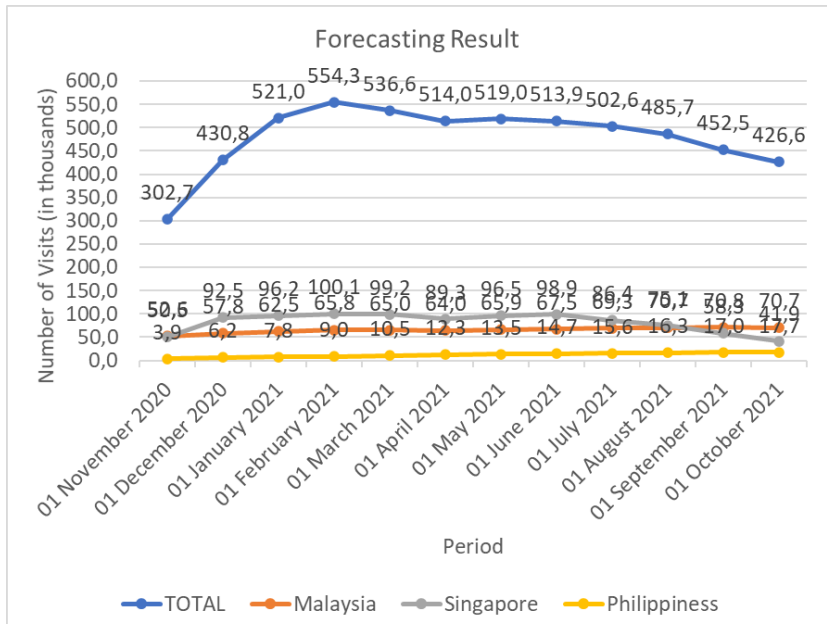

Figure 14 : Forecasting Results for the Next One Year

Based on the results of forecasting and social media trends that are widely used, it can be used as a basis for more targeted policies for the government and the tourism industry to increase the number of foreign tourists visiting Indonesia. The examples described above are only examples of policies that can be considered by the government and the tourism industry, and beyond that it can be further developed to make policies or other decisions that are more precise, effective and efficient based on forecasting results in order to increase the number of foreign tourist visits to Indonesia.

\section{CONCLUSION}

The results of this study indicate that the SVM has higher accuracy for forecasting the number of foreign tourist visits to Indonesia in the four datasets used. The dataset used is data on the number of monthly foreign tourist visits to Indonesia and divided into training data and testing data with a split data ratio of 7:3 and 9:1. The results of forecasting the number of foreign tourist visits to Indonesia for the next year can be used as a basis for making policies for the government and the tourism industry. The suggestions for future work are using other forecasting methods and using other parameter settings or performing parameter optimization for each method, such as specifying the $\mathrm{C}$ value range and using other types of kernels in the SVM, and optimized the parameter and hidden layer in Neural Network. Furthermore, adding a dataset with other attributes that affect the number of foreign tourist visits to Indonesia.

\section{REFERENCES}

[1] M. P. Raharyani, R. Regasari, M. Putri, and B. D. Setiawan, "Implementasi Algoritme Support Vector Regression Pada Prediksi Jumlah Pengunjung Pariwisata," J. Pengemb. Teknol. Inf. dan Ilmu Komput. Univ. Brawijaya, vol. 2, no. 4, pp. 1501-1509, 2018.

[2] M. Sowwam, Riyanto, D. Anindita, S. A. Riyadi, and R. M. Qibthiyyah, "Laporan Kajian Dampak Sektor Pariwisata Terhadap Perekonomian Indonesia," 2018.

[3] S. Herawati, "Peramalan Kunjungan Wisatawan Mancanegara Menggunakan Generalized Regression Neural Networks," J. INFOTEL Inform. Telekomun. Elektron., vol. 8, no. 1, p. 35, 2016, doi: 10.20895/infotel.v8i1.49. 
[4] Kementerian Pariwisata dan Ekonomi Kreatif RI, "Data on Monthly Foreign Tourists Visit in 2019,” 2019.

[5] Badan Pusat Statistik, "Perkembangan Pariwisata dan Transportasi Nasional Agustus 2020,” Ber. Resmi Stat., no. 110, pp. 1-12, 2019.

[6] A. Indrasetianingsih, I. Damayanti, and T. Susanto, "Analisis ARIMA Box Jenkins untuk Peramalan Jumlah Kunjungan Wisatawan Mancanegara di Indonesia," Semin. Nas. Mat. dan Apl., pp. 226-229, 2017.

[7] I. G. B. R. Utama, Pengantar Industri Pariwisata Tantangan \& Peluang Bisnis Kreatif, 1st ed. Yogyakarta: DEEPUBLISH, 2014.

[8] I. Heliany, "Wonderful Digital Tourism Indonesia Dan Peran Revolusi Industri Dalam Menghadapi Era Ekonomi Digital 5.0,” Destin. J. Hosp. dan Pariwisata, vol. 1, no. 1, pp. 21-35, 2019, doi: 10.31334/jd.v1i1.483.

[9] L. Rizkinaswara, "Pentingnya Teknologi dalam Sektor Pariwisata," Kementrerian Komunikasi dan Informatika RI, 2019. [Online]. Available: https://aptika.kominfo.go.id/2019/04/pentingnya-teknologi-dalam-sektorpariwisata/. [Accessed: 01-Mar-2020].

[10] I. J. Thira, N. A. Mayangky, D. N. Kholifah, I. Balla, and W. Gata, "Peramalan Data Kunjungan Wisatawan Mancanegara ke Indonesia menggunakan Fuzzy Time Series," J. Edukasi dan Penelit. Inform., vol. 5, no. 1, p. 18, 2019, doi: 10.26418/jp.v5i1.31074.

[11] C. C. Aggarwal, Data Mining: The Text Book. Yorktown Heights: Springer, 2015.

[12] H. Widyatmoko, A. S. Honggowibowo, and N. D. Retnowati, "Implementasi Data Mining Untuk Meramalkan Penjualan Di Minimarket Idola Jl Pati-Tambakromo Km 2 Desa Karangmulyo Rt 08 Rw 1 Dengan Metode Time Series," Compiler, vol. 1, no. 2, pp. 29-37, 2012, doi: 10.28989/compiler.v1i2.15.

[13] J. R. Saura, A. Reyes-Menendez, and P. R. Palos-Sanchez, "The Digital Tourism Business,” no. January, pp. 1-22, 2019, doi: 10.4018/978-1-52259783-4.ch001.

[14] J. Han, M. Kamber, and J. Pei, Data Mining Concept and Techniques, 3rd ed. Morgan Kaufman Publisher, 2011.

[15] K. Thirunavukkarasu and M. Wadhawa, "Analysis and Comparison Study of Data Mining Algorithms Using Rapid Miner," Int. J. Comput. Sci. Eng. Appl., vol. 6, no. 1, pp. 9-21, 2016, doi: 10.5121/ijcsea.2016.6102.

[16] M. S. Brown, Data Mining For Dummies. Hoboken: John Wiley \& Sons, Inc., 2014.
[17] R. J. Roiger, Data Mining A Tutorial-Based Primer. 2013.

[18] A. Koutras, A. Panagopoulos, and I. A. Nikas, "Forecasting Tourism Demand Using Linear and Nonlinear Prediction Models," Acad. Tur. Innov. Journa, vol. 9, no. 1, pp. 85-98, 2016.

[19] H. Yoon, S. C. Jun, Y. Hyun, G. O. Bae, and K. K. Lee, "A comparative study of artificial neural networks and support vector machines for predicting groundwater levels in a coastal aquifer," J. Hydrol., vol. 396, no. 1-2, pp. 128-138, 2011, doi: 10.1016/j.jhydrol.2010.11.002.

[20] A. Bode, "Perbandingan Metode Prediksi Support Vector Machine Dan Linear Regression Menggunakan Backward Elimination Pada Produksi Minyak Kelapa," J. Sist. Inf. dan Tek. Komput., vol. 4, no. 2, pp. 104-107, 2019.

[21] R. Maulana and D. Kumalasari, "Analisis Dan Perbandingan Algoritma Data Mining Dalam Prediksi Harga Saham Ggrm," J. Inform. Kaputama, vol. 3, no. 1, pp. 22-28, 2019.

[22] T. Setiyorini and Frieyadie, "COMPARISON OF LINEAR REGRESSIONS AND NEURAL NETWORKS FOR,” J. PILAR Nusa Mandiri, vol. 16, no. 2, pp. 135-140, 2020.

[23] H. Harafani and R. S. Wahono, "Optimasi Parameter Pada Metode Support Vector Machine Berbasis Algoritma Genetika untuk Estimasi Kebakaran Hutan,” J. Intell. Syst., vol. 1, no. 2, pp. 82-90, 2015.

[24] L. N. Smith, "Cyclical learning rates for training neural networks," Proc. 2017 IEEE Winter Conf. Appl. Comput. Vision, WACV 2017, pp. 464-472, 2017, doi: 10.1109/WACV.2017.58.

[25] S. Kemp, "Digital 2020: Malaysia," We Are Social, 2020. [Online]. Available: https://datareportal.com/reports/digital-2020-malaysia. [Accessed: 29-Jan-2021].

\section{AUTHORS}

First Author - Fahirah, Department of Management Information System, Gunadarma University, INDONESIA, eva190198@gmail.com

Second Author - Sutresna Wati, Department of Computer Engineering, Gunadarma University, INDONESIA, tresna.sw@gmail.com 